\title{
THE ROLE OF RISK BASED INTERNAL AUDIT IN IMPROVING AUDIT QUALITY
}

\author{
Erlina*, Abdillah Arif Nasution, Idhar Yahya and Agung Wahyudhi Atmanegara \\ Universitas Sumatera Utara, Medan, Indonesia \\ *Corresponding Author
}

\begin{abstract}
This research was conducted with the aim of identifying the internal auditor's understanding of Risk Based Internal Audit (RBIA), identifying the application of risk assessment and risk matrix in the Government of North Sumatra Province. Produce driving and inhibiting factors for the application of risk based internal audit in the Government of North Sumatra Province. This research was conducted using quantitative approaches. The research population is internal auditors in the local government, while the informants in this study are people who understand the problems of implementing Risk Based Internal Audit. The variables that are thought to affect the successful implementation of risk based internal audit are the role of the internal auditor function, top management commitment, training, policy framework, and communication processes. The results showed that top management commitment, training, policy framework had a significant effect on the success of risk management implementation, while the role of the internal audit function and the communication process had no significant effect on the application of risk based internal audit. The results showed that the application of risk based internal audit has a significant effect on the quality of internal audit.
\end{abstract}

\section{JEL Codes : M42}

Key words: risk based internal audit, top management commitment, training, policy framework, communication process.

Cite this Article: Erlina, Abdillah Arif Nasution, Idhar Yahya and Agung Wahyudhi Atmanegara, The Role of Risk Based Internal Audit in Improving Audit Quality, International Journal of Management, 11(12), 2020, pp 299-310.

http://iaeme.com/Home/issue/IJM?Volume=11\&Issue=12

\section{INTRODUCTION}

The government internal supervisory apparatus (GISA) functions to supervise the regional financial management process. The regional internal supervisory apparatus acts as an internal auditor in the government. The question is whether GISA P in the regions is able to develop the audit task with the various obstacles that exist such as limited audit staff with accounting 
backgrounds, lack of training, high transfer of audit personnel to other agencies. This problem can be overcome by changing the audit approach. Risk based internal auditing (RBIA), this approach is a risk-based audit that connects internal audit with the overall risk management framework of the organization. Through the RBIA method, internal auditors ensure that all organizational risk management processes have been carried out effectively. By implementing a risk-based audit approach, it is hoped that the auditors will be able to identify the risks of failure, error and fraud. Other benefits that will be obtained by internal auditors if they use a risk-based audit approach, including internal auditors will be more efficient \& effective in conducting audits, so as to improve the performance of the Inspectorate.

The current phenomenon is that the quality of work of the district/city government internal supervisory apparatus is still relatively low in carrying out its supervisory function. This can be seen from the results of the examination by the Supreme Audit Agency (SAA) on the implementation of the Regional Budget management at the Regency/City Government in North Sumatra Province. They still find some fraud that cannot be found by the internal supervisory apparatus of the City Regency Government. Based on the SAA findings, it indicates that the government internal supervisory apparatus has not been able to carry out its role and function properly and shows the inability of the government internal supervisory apparatus to detect and assess potential fraud. Before submitting local government financial reports to the SAA, the local government inspectorate must review the Regional Government Financial Reports. The increased ability to manage audit risk management will have an impact on the quality of the internal audit reports conducted by the government internal supervisory apparatus and make the BPK's tasks easier when carrying out general audits.

It is known that in recent years there has been a shift in the auditing approach, from a system-based audit to a process-based audit and now the current approach used in auditing is risk-based audit. With the shift in the auditing approach, many studies have been carried out related to Risk Based Internal Audit. Among them are research conducted by Eshikhati (2012), Kirogo et.al (2014), Nyarombe et.al (2015) and others. Eshikhati examines the factors that influence the implementation of public sector risk-based auditing in Kenya.

This research is a continuous research conducted by Erlina et.al in 2018, the results of their research concluded that the most important role in the successful implementation of Risk Based Internal Auditing is the commitment of top management. Without top management commitment, quality human resources, good regulatory framework, the implementation of Risk Based Internal Auditing will not succeed. Using the RBIA approach is indispensable to focus on the application and effectiveness of risk management procedures, risk assessment methodologies, critical evaluation of the adequacy and effectiveness of internal control systems. The role of the auditor will change to the person who has to suggest steps to reduce risk and identify areas of potential risk.

\section{LITERATURE REVIEW}

Risk Based Internal Audit is a risk based audit procedure. Risk-based internal audit, which focuses on recorded and unrecorded risks, improves financial reporting assurance and the process of reporting financial statements. The higher the risk area, the more time for the audit and supervision of the auditee. Apart from focusing on the level of risk, risk-based methods help to evaluate and build value into the financial reporting process. To do this, auditors must have up-to-date insight. The knowledge gathered can help design an audit program that includes the most effective and efficient test combinations responsive to each client's unique circumstances. For this reason, the risk-based approach is then superior to traditional auditing methods (Gibson, 2003). 
Risk-based audit theory argues that experience can enhance the auditor's ability to assess future risks accurately. However, psychology shows that individuals tend to overestimate experiences when confronted with current risk cues as opposed to experience. The audit risk theory argues that the auditor's evaluation during the audit becomes more effective with the experience he has. Conversely, there is a risk that the auditor will rely on experience, which is apparently backward in nature, in addition to gaining specialized knowledge. Risk-based internal audit is applied to the internal control and risk management system, which requires all departments to build risk management awareness, identify risk control points, take appropriate steps to control, and record various risk controls, create risk-based internal audits from important data sources (Doolin and Lawrence, 1997). According to this theory, the responsibility for identifying and managing risks belongs to management, while one of the main roles of internal audit is to provide assurance that these risks have been properly managed (Alexander, 1991). The professional internal audit activity can achieve its mission as the best foundation for governance by positioning its work within the context of the organization's own risk management framework. This involves looking at how managers identify, assess, respond to and report risks, as well as how well managers monitor how responses to risk work.

The Chartered Institute of Internal Auditors (2014) states that risk-based internal audit (RBIA) is a methodology that links internal audit to the overall risk management framework of an organization. RBIA enables internal audit to provide assurance to the board that risk management processes are managing risk effectively, given risk appetite.

By following an internal audit, RBIA should be able to conclude that:

1. Management has identified, assessed and responded to risks above and below appetite for risk

2. The response to risk is effective but not excessive in managing the risks inherent in those risks

3. If the residual risk is not in line with the appetite for risk, action is taken to remedy it

4. Risk management processes, including the effectiveness of response and action completion, are being monitored by management to ensure they continue to operate effectively

5. Risks, responses and actions are properly classified and reported.

Goodwin-Stewart and Kent (2006) stated that internal audit plays an important role in monitoring a company's risk profile and identifying areas to improve risk management. The object of internal audit is to increase the efficiency and effectiveness of the organization through constructive criticism. In general, internal audit has become an indispensable management tool for achieving effective control in both public and private organizations. RBIA is a methodology that links internal audit with the entire organization's risk management framework. Through RBIA, internal auditors ensure that all organizational risk management processes have been carried out to manage risk effectively.

Why do internal auditors have to change the paradigm? Didn't they originally become part of the organization and function to support management? Internal auditors have indeed been designed to be part of the organization and support management. Therefore, internal auditors must have the same language and orientation as management. Unfortunately, the old paradigm of internal audit has not used the same language as management. The old paradigm that emphasizes control-based aspects is considered no longer relevant because it is not directly connected to the focus of management objectives. Focus on aspects of control may direct the auditor to areas / areas that are not actually the focus of management objectives. As a result, the results of internal audits do not have a direct impact on achieving objectives. 
The attention of internal auditors is shifted by this RBIA paradigm, to focus more on risk. Risks are things that hinder the achievement of organizational goals. This focus on risk gives auditors the same language as management's will. It is also hoped that the achievement of organizational goals will be easier because the risks have been well identified and all countermeasures have been tested for reliability through the internal audit process.

According to Erlina et. al (2018a) Internal auditors need to change their approach to conducting internal audits in local governments, from the traditional approach to risk based auditing. In general, the changes are:

1. Internal audit is the first to assist or become a consultant for Regional Apparatus Organizations (OPD) in conducting a risk matrix, if the OPD has not yet conducted / created a risk matrix

2. Risk-based audit planning uses more audit time in high-risk areas and is the most important government activity

3. Ensuring that the limited number of internal auditors has been optimally empowered. Due to limited auditor resources (HR), time and costs, risk-based audits can save the company budget and be more efficient because the priority is in areas with high risk, both in terms of the likelihood of their occurrence and impact.

4. Change the mindset of the examining apparatus, that performance and reward are based on the number of activities examined.

5. Approaches from past orientation where risks have occurred towards the future by providing early warning of possible risks that will be faced by the company in the future.

As a result of changing organizational needs, technology and the complexity of the organization's activities and systems, the nature of the services internal auditors are looking for has changed over the years from an emphasis on traditional compliance auditing where independence has become the main paradigm for value-bearing roles where partnerships with management are meaningful larger (Abdolmohammadi et al., 2006 and Erlia, 2018b).

In order for internal audit to be efficient, it requires continuous training from internal auditors. Internal auditors are people who have a high level of knowledge, knowledge, skills and abilities, and follow international standards in assessment standards, ensuring more effective control (McKee, 2006). Auditors are difficult to detect fraud and one of the reasons why internal auditors find it difficult to track and detect fraud is because they do not have sufficient experience in identifying falsified financial data (Hammersley et al., 2011). Training involves stimulating fraud cases that make internal auditors gain significant experience (Bierstaker et al., 2012), improve performance and improve their ability to detect evidence suggesting fraud. In their research on current control practices by copying with employee fraud and organizational risk, Zanzig \& Flesher (2011) compared US and Canadian firms' fraud detection conditions with desired conditions with respect to risk management training, understanding fraud management procedures, recognition of key fraud indicators. and incentives to report fraud. They concluded that employee training to manage fraud is a training that needs to be improved. Finally, Bierstaker et al. (2012) examined the impact of auditor training on detecting fraud.

Risk indicators monitor risk exposure, as an early warning system, taking action to minimize losses. Risk monitoring in the company is carried out through the Dashboard interface. Risk is generated by uncertainty. It should be monitored using key risk indicators that do this when executing the chosen strategy. Thresholds are set for the Key Risk indicators to trigger action to adjust the chosen strategy to combat risk. When strategies are reviewed, there are new risk indicators and new trigger points. This procedure increases the chances of achieving the goals and strategies chosen by management [Mark S. Beasley, Bruce C. Branson, Bonnie V. Hancock, 2010]. 
The Main Risk Indicator reflects what is accepted or not and the trend towards company risk. Since Key Risk indicators can be measured, they help communicate expectations for risk. The measurement frequency is an important factor. In general, the more frequently an indicator is revised, the more representative information will be obtained. There will be cases where frequently the indicator measurement will show small changes in the risk profile. In this situation, it is important to consider trends before drawing conclusions. Trends show if risk exposure decreases or increases.

Risk management has four main phases to implement; risk identification, risk assessment, risk priority and response planning. Fraser et al (2010) stated that there are separate roles for the internal auditors and risk management functions. In addition, they limit the role of internal audit by providing top management with independent assurance regarding the effectiveness of risk management, by ensuring the effectiveness of controls, risk management processes, managing key risks, and reliability, in addition to the appropriateness of assessing and reporting risks and controls. In particular, achieving independence and objectivity in these activities seeks a separation in the roles between risk management and internal audit (Bazerman et al, 1997 and Habbe et al., 2019).

Meaningful communication informs and educates employees at all levels and motivates them to support strategies (Barrett, 2002). This is important because a positive attitude towards change is very important in the success of implementing Risk Based Internal Auditing, because resistance to change is one of the biggest obstacles to overcome. Meaningful communication requires a level of 'cognitive organizational reorientation' (Elving, 2008) that is understanding and appreciation of the proposed changes. Elving and Hansma (2008) conducted an interview study between management and employees during organizational change. The most important conclusion drawn is that the successful deployment and adaptation of organizational change significantly depends on the communicative and informative skills of managers at all levels. Although leaders seem to be aware of important changes in organizations, communicating about those changes is very difficult. Bennebroek-Gravenhorst et al. (2006) found that along with management's role in the contribution of the workforce to impending changes, the distribution of information and actual communication regarding the need for change and the purpose of modification in business organizations is also very important.

The research was conducted using a quantitative approach in which the suspected factors were hypothesized from several previous studies. The hypothesis are:

1. The communication process, The role of the internal audit function, Training, Top management commitment, and Risk management have a positive effect on the successful implementation of Risk Based Internal Audit (RBIA).

2. The successful implementation of Risk Based Internal Audit (RBIA) has a positive effect on audit quality.

\section{METHOD}

This research was conducted using a quantitative approach. The research population is internal auditors in the local government, while the informants in this study are people who understand the problems of implementing Risk Based Internal Audit. The variables that are thought to influence the successful implementation of risk based internal audit are the role of the internal auditor function, top management commitment, training, policy framework, and communication processes. 


\section{RESULTS AND DISCUSSION}

\subsection{Result}

Based on data calculations using the PLS algorithm, the loading factor value of each variable indicator can be seen in Figure 1 and table 1. The test is carried out 2 (two) times because in the first stage there are several question items that have a loading factor below 0.5 .

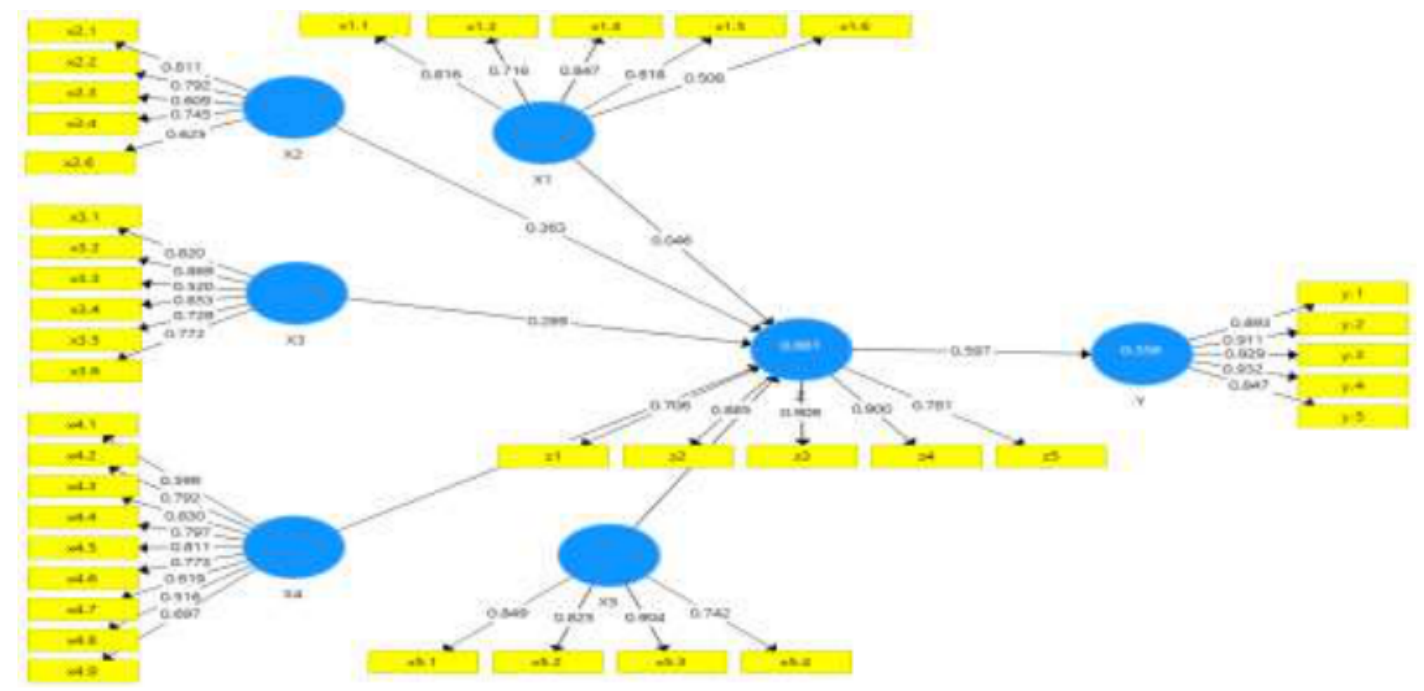

Figure 1 Loading Factor Level 2

Table 1 Cronbach's alpha and Average Variance Extracted (AVE)

\begin{tabular}{|c|c|c|c|c|}
\hline & Cronbach's Alpha & rho_A & $\begin{array}{c}\text { Composite } \\
\text { Reliability }\end{array}$ & $\begin{array}{c}\text { Average Variance } \\
\text { Extracted (AVE) }\end{array}$ \\
\hline X1 & 0,799 & 0,828 & 0,863 & 0,564 \\
\hline X2 & 0,764 & 0,778 & 0,842 & 0,520 \\
\hline X3 & 0,857 & 0,883 & 0,895 & 0,592 \\
\hline X4 & 0,882 & 0,891 & 0,906 & 0,522 \\
\hline X5 & 0,852 & 0,882 & 0,900 & 0,692 \\
\hline Y & 0,943 & 0,947 & 0,957 & 0,815 \\
\hline Z & 0,893 & 0,900 & 0,922 & 0,705 \\
\hline
\end{tabular}

Based on Figure 1, it can be seen that all indicator items are declared valid, this can be seen in the loading factor value greater than 0.5 , which means the indicator is declared valid so that it is suitable for use in this study. In addition to the loading factor value, to meet the convergent validity it is necessary to know the Average Variance Exctracted (AVE) value. Average Variance Extracted (AVE) value must be greater than 0.5. The provisions regarding the measurement parameters (rule of thumb) of the measurement model (outer model) that $\mathrm{AVE}$ is considered to have met convergent validity if the AVE value is greater than 0.50 (Ghozali and Latan, 2017). So based on table 1 the AVE value, it can be seen that the AVE value of each construct is $>5$. So the construct has met the convergent validity.

The PLS multiple regression results on the inner model can be seen in table 2. The results of the study concluded that the top management's commitment and the communication process had no effect on the successful implementation of risk management. The successful implementation of risk management affects the quality of internal audit. 
Table 2 Path Coeficient Value

\begin{tabular}{|c|c|c|c|c|c|c|}
\hline & $\begin{array}{c}\text { Original } \\
\text { Sample } \\
(\mathbf{O})\end{array}$ & $\begin{array}{c}\text { Sample } \\
\text { Mean (M) }\end{array}$ & $\begin{array}{c}\text { Standard } \\
\text { Deviation } \\
\text { (STDEV) }\end{array}$ & $\begin{array}{c}\text { T Statistics } \\
(|\mathbf{O} / \mathbf{S T D E V}|)\end{array}$ & P Values & Decision \\
\hline $\mathrm{X} 1->\mathrm{Z}$ & 0,046 & 0,045 & 0,060 & 0,757 & 0,449 & Rejected \\
\hline $\mathrm{X} 2->\mathrm{Z}$ & 0,363 & 0,370 & 0,065 & 5,588 & 0,000 & Accepted \\
\hline $\mathrm{X} 3->\mathrm{Z}$ & 0,269 & 0,257 & 0,103 & 2,601 & 0,010 & Accepted \\
\hline $\mathrm{X} 4->\mathrm{Z}$ & 0,226 & 0,234 & 0,092 & 2,465 & 0,014 & Accepted \\
\hline $\mathrm{X} 5->\mathrm{Z}$ & 0,038 & 0,036 & 0,053 & 0,705 & 0,481 & Rejected \\
\hline $\mathrm{Z} \mathrm{->} \mathrm{Y}$ & 0,597 & 0,601 & 0,047 & 12,707 & 0,000 & Accepted \\
\hline
\end{tabular}

\subsection{Discussion}

The results showed that top management commitment, training, policy framework had a significant effect on the successful implementation of risk management, while the role of the internal audit function and the communication process had no significant effect on the application of risk based internal audit. The results showed that the application of risk based internal audit has a significant effect on the quality of internal audit. The results of this study support the results of research conducted by Erlina which states that management commitment has a positive and significant effect on the success of risk-based internal audit absorption. The results of this study are different from Erlina's research where in this study training has a positive and significant effect on the successful implementation of RBIA.

Respondents said that the evidence that the communication process between internal auditors and top management in regional apparatus organizations has not been going well, as well as communication between internal auditors and employees in the auditee environment has not been going well. There is still a sense of suspicion from the auditee about the presence of the auditors when they carry out the audit. If good communication has been built, then the steps offered by various experts in implementing risk-based audits will go well. Management teams often have limited understanding of the communication dynamics within their organization. This can result in a climate of mutual suspicion rather than trust, with energy focused more on solving internal problems. They suggest that the key to building a good communication system lies in managers who have an accurate picture of how well they and others actually communicate through training.

The results showed that the communication process had a positive and significant effect on the successful application of risk based internal audit. Effective communication between superiors and subordinates, between auditees and auditors. Communication processes that are not running well will hinder the implementation of a system both in companies and in local governments. As explained in the previous chapter, communication is the process of sending information and mutual understanding from one person to another (Keyton, 2011). The importance of communication during the intended changes has been demonstrated empirically and mutually agreed among practitioners. Communication failure can lead to non-functioning outcomes such as stress, job dissatisfaction, low trust, decreased organizational commitment, severance pay, and absence and this can negatively affect organizational efficiency (Zhang \& Agarwal, 2009). Communication during organizational change reduces resistance to change. When the resistance to change is low in an organization, the change effort is more productive. Change plans depend on the organizational capacity to change the individual performance of each employee (Goodman \& Dean, 1982; Robertson et al., 1993, Tannenbaum, 1971). Since organizational change introduces a variety of tasks assigned to each employee, sending these employees information about future changes is an important and integrative part of the change strategy. Based on previous research, good communication which explains the importance of 
implementing risk based internal audit will have a positive impact on the acceptability of a change in an approach in auditing.

Meaningful communication informs and educates employees at all levels and motivates them to support strategies (Barrett, 2002). This is important because a positive attitude towards change is very important in the success of implementing Risk Based Internal Auditing, because resistance to change is one of the biggest obstacles to overcome. Meaningful communication requires a level of 'cognitive organizational reorientation' (Elving and Hansma, 2008), namely understanding and appreciation of the proposed changes. Elving and Hansma (2008) conducted an interview study between management and employees during organizational change. The most important conclusion drawn is that the successful deployment and adaptation of organizational change significantly depends on the communicative and informative skills of managers at all levels. Although leaders seem to be aware of important changes in organizations, communicating about those changes is very difficult. Bennebroek-Gravenhorst et al. (2006) found that along with management's role in the contribution of the workforce to impending changes, the distribution of information and actual communication regarding the need for change and the purpose of modification in business organizations is also very important.

The communication process is very important, so a good strategy is needed in the communication process. According to Klein (1996), the communication strategy must coincide with the general stages of the change process and the relevant information requirements that are relevant. In this case, it is necessary to have good communication by the leadership towards members of the organization for changes that will be made in the application of risk based internal auditing. Because a good communication process is one indicator that will have a good effect on the application of RBIA. The communication aspect must be emphasized in implementing a risk-based audit process. Although research indicates that communication is a key success factor in adopted risk-based audits that communicate with employees regarding issues related to RBIA that are often delayed.

Respondents face challenges and frequent misunderstandings about how the auditor determines several audit procedures during the audit. Respondents feel that they do not have independence in carrying out their duties, it is difficult to carry out supervision that is more focused on an activity that they consider to have a high risk of error and fraud, often DPOs think that the inspectorate seems to be only looking for mistakes when they try to detect illegal and / or fraudulent acts. Meanwhile, on the one hand, audit report users have high expectations of the inspectorate in meeting and handling audit findings.

Often the inspectorate is disappointed because the audit findings are not followed up on the findings. Respondents feel their role in carrying out its function as internal audit has limitations. The considerable criticism and litigation of the inspectorate as an audit apparatus indicates a gap between public expectations of auditors and the perceived performance of auditors by the organization.

Based on the research results, the clarity of the role of the inspectorate function is needed so that the implementation of risk based internal audit runs well. In local governments, both auditees and auditors do not understand the role of internal auditors in the risk based internal audit implementation stage. This will clearly hamper the application process of risk based internal audit. If the auditee and auditors understand the stages of implementing the RBIA raised by Griffith, the RBIA implementation will run smoothly.

Inappropriate training can lead to a lack of commitment to proper work procedures, poor supervision and demoralized staff. This could mean that the level of service provided in the organization is not up to standard and therefore changes are needed. Managers at every level of the organization are responsible for ensuring that employees have the skills needed to do 
the work required. Carrying out this managerial task includes providing effective training to team members on work policies and procedures and existing standards and regulations, as well as recognizing the need for skills-based training and ensuring that it is available to employees who need it.

The results of this study are in line with the literature review and research results that have been previously stated. The results of the study concluded that the training had an effect on the successful implementation of RBIA. So far, the form of training provided to local government internal auditors has not been felt to be effective and efficient. The training held by certain institutions does not touch the needs of internal auditors. In addition, there is a tendency for local government employees, when given training, they carry out the training because an obligation is not a necessity. So that the results they receive are not optimal. Local governments need to think about changing the form of training. In house training may be an alternative that can be applied by local governments. Training must be on an ongoing basis. It is necessary to establish a forum for discussion between internal auditors so that the problems they get in carrying out their duties can be discussed together so that the solutions they take are not subjective and individual. If it is individual, then if there is the same problem, then the solution is the same.

Top management commitment is seen as critical across regional organizations for effective RBA implementation. Employees at all levels of the organization feel that top management does not support the implementation of RBIA. Respondents recommended internalizing strategic risk management principles so that all employees become more effective. The results showed that top management commitment had a significant effect on the successful implementation of RBIA. This contradicts the literature review and previous research results. As with the results of interviews with several respondents, there is a tendency for the leadership to not really care about risk based internal audit, they do not understand the benefits of implementing a risk-based audit approach.

The success of implementing risk-based audits if all organizational units, in this case regional organizations, have implemented risk management. If the regional apparatus organization has not implemented risk management, it will be difficult for the auditors to conduct a risk-based audit. Internal auditors can provide consulting services that improve organizational governance, risk management, and control processes. The level of consultation with the internal auditors will depend on other resources, internal and external, available to the board and on the risk maturity of the organization and may vary over time. The internal auditors' expertise in considering risk, in understanding the relationship between risk and governance and in facilitation means that the internal audit activity qualifies for action, particularly in the early stages of its introduction. As the organization's risk maturity increases and risk management becomes more embedded in business operations, the role of internal audit in championing risk management may diminish. Likewise, if an organization employs specialist services or a risk management function, internal audit is more likely to value it by concentrating on its underwriting role, rather than by engaging in more consulting activities. However, if internal audit has not adopted a risk-based approach represented by assurance activities it may not be equipped to carry out consulting activities at the center.

Internal audit can expand its involvement in risk management under certain conditions as follows:

1. It must be clear that management remains responsible for risk management.

2. The nature of the internal auditors' responsibilities shall be documented in the internal audit charter and approved by the audit committee.

3. Internal audit must not manage any risk on behalf of management. 
4. Internal audit must provide advice, challenge, and support for management decision making, not take risk management decisions on its own.

5. Internal audit also cannot provide objective assurance on any part of the ERM framework for which it is responsible. Such warranties must be provided by another suitably qualified party.

6. Any work outside of the guarantee activity shall be recognized as a consulting engagement and the implementation standards associated with that engagement shall be followed.

The core role of Internal Audit is to provide assurance to management and the board of risk management effectiveness. When guarantees cannot be provided, the responsibility rests with management to implement the appropriate response. Internal audit may still make recommendations, but this is part of a 'consulting' role. In the context of RBIA, internal audit can only provide assurance where a risk management framework exists.

By maintaining its independence, internal audit can conduct its assessments objectively, providing unbiased and informed management and board and governance processes, risk management, and internal control. Internal audit strengthens corporate governance through risk-based audits that provide assurance and insight into the processes and structures that drive the organization to success. As risks grow and become more complex, the role of internal audit is likely to expand in areas such as risk governance, culture and behavior, sustainability, and other non-financial reporting measures.

\section{CONCLUSIONS AND SUGGESTIONS}

Based on the results of research using qualitative methods, it is concluded that the local government inspectorate has not implemented a risk-based audit approach. Risk based internal audits have not been carried out by the Regional Government APIP for various reasons raised. Based on the results of the interviews, some respondents concluded that the Regional Apparatus Organization (OPD) was not ready to carry out an examination using a risk-based approach. In addition, the research team concluded that some of the respondents did not understand RBIA so that they were unable to explain the process that must be carried out to implement a Risk Based Internal Audit.

The steps that must be taken to plan a risk based audit (risk based internal audit) are as follows:

1. Compile an audit universe and establish auditable units within the organization

2. Determine and design risk factors that are determined to be calculated such as:

a. Budget

b. Adequacy of internal control

c. Support for audit findings

d. Competence / adequacy of employee integrity

e. Public attention

f. Number of activities

g. Performance achievements

3. Choose the appropriate format for assessing risk factors

4. Determine a method for setting audit priorities for each auditable unit. All risk factors selected in this study were calculated using scoring criteria.

In an effort to increase the adoption of RBIA, respondents recommended strengthening the monitoring of auditor performance, improving the quality of supervision across DPOs, improving the education of audit practitioners, introducing new auditing standards, and educating the public about the audit function and auditors' work. Most of the respondents 
talked about providing understanding to users as one approach to increase the level of user understanding and reduce differences in perceptions. Overall, the main solution lies in increasing the level of auditor independence and accountability of auditors with more punitive measures to reduce government reporting scandals and thus pave the way for improving audit quality.

\section{REFERENCES}

[1] Abdol Mohammadi, M.J., Burnaby, P., Hass, S. (2006), "A review of the common body of knowledge (CBOK) studies in internal auditing and an overview of the global CBOK 2006", Managerial Auditing Journal, 21(8).811-21.

[2] Christensen, J. G. (1992). Hierarchical and Contractual Approaches to Budgetary Reform. Journal of Theoretical Politics. 4 (1). 67-91.

[3] Erlina, Putri, D. R., Sopanah, A., \& Young, I. (2018). A Model of Successful Risk Based on Internal Audit Implementation in Regencies / Cities In North Sumatra, (October).

[4] Erlina, Putri, D.R, Sopanah, A (2018b). Model of Successful Risk Based Internal Audit Implementation in Regencies/Cities in North Sumatera. International Journal of Civil Engineering and Technology. 615-627. http://www.iaeme.com/IJCIET/issues.asp?JType=IJCIET\&VType=9\&IType=9

[5] Erlina. (2011). Business Research Methodology for Accounting and Management. Second Edition, Second Printing, USU Press, Medan.

[6] Eshikhati, Lutta S. (2012). Determinants of Adoption of Risk Based Audits in the Public Sector in Kenya, Thesis. Nairobi: Department of Business Administration University of Nairobi.

[7] Fozzard, A. (2001). The Basic Budgeting Problem: Approaches to Resource Allocation in The Public Sector and Their Implications for Pro-Poor Budgeting, Overseas Development Institute, London.

[8] Fraser, J. \& Simkins, B.J. (2010). Enterprise Risk Management, Today's Leading Research and Best Practices for Tomorrow's Executives, USA, John Wiley \& Sons Ltd.

[9] Gibson, M.S. (2003), Is corporate governance ineffective in emerging markets?", Journal of Financial and Quantitative Analysis, 38 No.1,231-50. IIA (2004), International Standards for the Professional Practice of Internal Auditing, Institute of Internal Auditors, Altamonte Springs, FL.

[10] Goodman, P. S. \& Dean, J. W. (1982). Creating long-term organizational change. In Goodman, P. S. (Eds.), Change in Communication (pp. 226-279). San Francisco: Jossey-Bass.

[11] Griffiths, David (2006), Risk Based Internal Auditing - Three Views On Implementation. March 2006.

[12] Habbe, A.H., Rasyid, S., Arif, H., (2019). Measuring internal auditor's intention to blow the whistle (A Quasi-experiment of internal auditors in the local government). Business: Theory and Practice. 20 224-233.

[13] Keyton, J. (2011). Communication and organizational culture: A key to understanding work experience. Thousand Oaks, CA: Sage.

[14] Kirogo, F. K., Ngahu, S., \& Wagoki, J. (2014). Effect of Risk-Based Audit on Financial Performance: A Survey of Insurance Companies in Nakuru Town, Kenya. IOSR Journal of Business and Management, 16 (10), 84-91

[15] Latan, H., \& Ghazali, I. (2017). Partial Least Squares, Concepts, Methods and Applications Using WarPLS 5.0, Third Edition. Diponegoro University Publisher Agency. 
[16] Lupia, Arthur and Mathew McCubbins. (2000). Reprensentation of Abdicaton / How Citizens Use Institutions to Help Delegation Succeed. European Journal of Political Research, Vol. 37, Hal. 291-307.

[17] Lupia, Arthur. (2001). Delegation of Power: Agency Theory, published in Neil J. Smelser; and Paul B.

[18] McCubbins, M. D; R. G. Noll; and B. R. Weingast. (1987). Administrative Procedure as Instruments of Political Control. Journal of Law, Economic and Organization. 3: 243-79.

[19] Mitnick, B.M. (1973). Fiduciary Responsibility and Public Policy: The Theory of Agency and Some Consequences. Presented at the American Political Science Association Annual Meeting, 69th. New Orleans, Los Angeles.

[20] Nyarombe, F., Musau, E. G., Kavai, I., \& Kipyegon, K. (2015). The effect of risk based audit approach on the implementation of internal control systems: a case of Uasin Gishu County. International Journal of Business and Management Invention, 4 (1), 12-32.

[21] Van Gansberghe, C.N. (2005). Internal auditing in the public sector: a consultative forum in Nairobi, Kenya, shores up best practices for government auditing professionals in developing nations". Internal Auditor, August, 77(3). 69-73

[22] Waterman R. W; and K. J. Meier. (1998). Principal-agent models: an expansion ?, Journal of Public Administration. 8: 173-202. 